\title{
An Association of Education and Income with Convenient Payment Mode in the E-tail Industry during the COVID Pandemic
}

\author{
Gurumoorthy. $\mathrm{K}^{* 1}$, Dr. V. Sasirekha ${ }^{2}$ \\ ${ }^{I}$ Research scholar, Department of Management, Bharathiar University, Coimbatore, India \\ E-mail: gurumoorthy.mba@gmail.com \\ ${ }^{2}$ Professor, Department of Management, Sri Sairam Engineering College, Chennai, India
}

\begin{abstract}
E-tailing is the process of selling the goods and services to the large number of customers in the smaller quantity through the internet platform. Indian e-tailing sector is showing a burgeoning growth during the COVID Pandemic. The main purpose of the study is to test the association of the demographic variables Education and Income with the customer's preference towards the mode of payment. The scope of the study is confined with both the tangibles and the intangibles in horizontal e-tailers. The sampling frame of the study is the respondents those who have a previous experience in buying goods from the horizontal e-tailers. The purposive sampling technique was adapted to choose the respondents. The sample size was 620 respondents. The data was collected during COVID pandemic in India. The data analysis tool was the Chi-square test. The result from the data analysis indicates that both the education and income of the customers are related to the customer's preference towards the convenient mode of payment during the online shopping. The suggestions and conclusions are discussed further in detail.
\end{abstract}

Keywords - COVID Pandemic; Education; E-tailing; Income; Payment Mode.

\section{Introduction}

E-tailing is the adaptation of modern e-commerce technology in the conventional retailing business model. It is defined as the process of selling goods and services in a smaller units to the large number of customers through the online or internet. Due to COVID pandemic since March 2020 in India, the total sale of goods \& services in e-tailing shown a phenomenal growth with Indian e-tailing is the fastest growing industry globally with $27 \%$ Compounded Annual Growth Rate (Business today, July 2021).

It indicates that post COVID, the rate of digitization in payment has increased in India (Siby, 2021). When studying the customer preference on the mode of payment before the COVID, Indian customers prefer to buy through Cash on Delivery mode (Kha \& Jain, 2018).

The scope of the study is confined with both tangibles and intangibles in horizontal e-tailers i.e. multiple-product and multi-branded e-tailers like Amazon India, Flipkart and Snapdeal etc in India.

The purpose of the present research is to analyse the association of the demographic variables Education and Income with the customer preference towards mode of payment. It also going to study the customer preference towards various modes of payment based on their convenience. This study used demographic variables Education and Income as independent variables.

\section{Review of Literature}

According to Abu-Shamaa et al (2016), the mode of payment influences the purchase intention of the customers in online shopping. According to Antinoja \& Scheling (2019), customer's convenience plays an important role in choosing the payment method. According to Bandi et al (2019), the Indian online customers started moving to digital payment from conventional cash on delivery option after the demonetization in the year 2016. People using digital payment are increasing their frequency of purchase and the intention of returning the products decreases (Bandi et al,2019). According to Khan \& Jain (2018), even though the digital payment methods reach is increasing in India, still significant amount of customers stick towards cash on delivery option citing the reason that there is lack of security and convenience in digital payments. According to Siby (2021), the usage of digital payment increases in Indian e-tail industry even during COVID situation. According to Mallesha (2020), the rural India is still prefer cash on delivery option due to lack of awareness on technology and threat on security issues in digital payment systems.

\section{Research Methodology}

The research design of the study is single crosssectional descriptive research. It means the data was collected from single group with only once in the whole study. The data used in this study is the primary data. The 
population of the study is the greater Chennai city. The sampling frame of the study is the respondents those who have a previous experience in buying goods from the horizontal e-tailers. The purposive sampling technique is adapted to choose the respondents. The sample size is 620 respondents. The data was collected after the COVID lockdown i.e. during the August 2021. The data collection method is the online survey method with Google Form. The study variables Education, Income and Convenient Payment Method are categorical in nature. The Percentage analysis was used for the data classification and the Chisquare analysis was used to test the association of the demographic variables with the convenient payment mode.

\section{Research Hypothesis}

H1 - There is an association between Education and Convenient Payment Mode.

$H 2$ - There is an association between Income and Convenient Payment Mode.

\section{Data Analysis and Interpretations}

\subsection{Percentage Analysis of Demographic Variables}

The Percentage analysis of the demographic variables Education and Incomes are displayed in the below table (1).

Table 1. Percentage Analysis of Education and Income

\begin{tabular}{|c|l|l|l|}
\hline $\begin{array}{c}\text { Demographic } \\
\text { Factor }\end{array}$ & \multicolumn{1}{|c|}{ Category } & Frequency & Percentage \\
\hline Education & Post-Graduate & 210 & $34 \%$ \\
\cline { 2 - 4 } & Graduate & 330 & $53 \%$ \\
\cline { 2 - 4 } & $\begin{array}{l}\text { School Passed } \\
\text { Out }\end{array}$ & 80 & $13 \%$ \\
\cline { 2 - 4 } & Total & 620 & $100 \%$ \\
\hline \multirow{5}{*}{ Income } & Below 50k INR & 190 & $31 \%$ \\
\cline { 2 - 4 } & 50k-1lakh INR & 310 & $50 \%$ \\
\cline { 2 - 4 } & $\begin{array}{l}\text { Above 1 lakh } \\
\text { INR }\end{array}$ & 120 & $19 \%$ \\
\cline { 2 - 4 } & Total & 620 & $100 \%$ \\
\hline
\end{tabular}

Source: Primary data
When the educational qualification is concerned, more than half of the respondents are graduates. One third of the respondents are post-graduates and the rest are school passed outs. In monthly income, half of the respondents earn in the range of 50000 to 1 lakh INR; one-fifth of the respondents earn above 1 lakh INR and the rest of them earn below 50000 INR per month.

\subsection{Percentage Analysis of Convenient Payment Mode}

The customer preference towards the mode of payment is the significant study variable during this post COVID situation. In this analysis, five most used payment options are studied.

Table 2. Percentage Analysis of Convenient Payment Mode

\begin{tabular}{|l|l|l|}
\hline Payment Mode & \multicolumn{1}{|c|}{ Frequency } & \multicolumn{1}{c|}{ Percentage } \\
\hline Cards & 110 & $18 \%$ \\
\hline Internet banking & 80 & $13 \%$ \\
\hline UPI & 160 & $25 \%$ \\
\hline E-Wallet & 120 & $20 \%$ \\
\hline Cash on Delivery & 150 & $24 \%$ \\
\hline Total & 620 & $100 \%$ \\
\hline
\end{tabular}

Source: Primary data

From the above table (2), it is inferred that one-fourth of the respondents prefer UPI (Unified Payment Interface); another one-fourth of the respondents prefer cash on delivery option; one-fifth of the respondents prefer EWallet (Electronic Wallet); approximately another one-fifth prefer plastic cards (Credit/ Debit cards) and the rest of them prefer internet banking.

\subsection{Chi-square Analysis}

Chi-square analysis is used to test the association or relationship between two categorical variables (Mchugh, 2013). The table 3 depicts the cross tabulation between the educational qualification of the customers and their preference towards mode of bill payment in online shopping.

Table 3. Cross tabulation between Education and Payment Mode

\begin{tabular}{|c|c|c|c|c|c|c|c|}
\hline \multirow{2}{*}{\multicolumn{2}{|c|}{ Education }} & \multicolumn{5}{|c|}{ Payment Mode } & \multirow[t]{2}{*}{ Total } \\
\hline & & Cards & Internet Banking & UPI & E-Wallet & Cash On Delivery & \\
\hline \multirow{2}{*}{$\begin{array}{l}\text { Post- } \\
\text { Graduate }\end{array}$} & count & 40 & 20 & 68 & 52 & 30 & 210 \\
\hline & Percentage & $7 \%$ & $3 \%$ & $11 \%$ & $9 \%$ & $4 \%$ & $34 \%$ \\
\hline \multirow[t]{2}{*}{ Graduate } & count & 62 & 53 & 84 & 61 & 70 & 330 \\
\hline & Percentage & $10 \%$ & $9 \%$ & $13 \%$ & $10 \%$ & $11 \%$ & $53 \%$ \\
\hline
\end{tabular}




\begin{tabular}{|l|l|l|l|l|l|l|l|}
\hline \multirow{2}{*}{$\begin{array}{l}\text { School } \\
\text { Passed- out }\end{array}$} & count & 8 & 7 & 8 & 7 & 50 & 80 \\
\cline { 2 - 8 } & Percentage & $1 \%$ & $1 \%$ & $1 \%$ & $1 \%$ & $9 \%$ & $13 \%$ \\
\hline \multirow{2}{*}{ Total } & count & 110 & 80 & 160 & 120 & 150 & 620 \\
\cline { 2 - 8 } & Percentage & $18 \%$ & $13 \%$ & $25 \%$ & $20 \%$ & $24 \%$ & $100 \%$ \\
\hline
\end{tabular}

Source: Primary data

From the above table (3), it is inferred that $13 \%$ of the total respondents are graduates who prefer UPI as mode of payment; $11 \%$ of the total respondents are post-graduates who prefer UPI; another $11 \%$ of the respondents are graduates who prefer cash on delivery; and $9 \%$ of the total respondents are school passed outs who prefer cash on delivery. The summary of the above findings states that people with higher level of education prefer UPI and simultaneously majority of less educated prefer cash on delivery option. The chi-square test value for the above table is 121.79 with degree of freedom is 8 . The probability value is 0.000 , which is below 0.05 . Hence the alternative hypothesis is accepted. Therefore the education is related to the convenient payment mode. The table 4 shows the cross tabulation between the monthly income of the online customers and the customer's preference towards the mode of bill payment to the e-tailers.

Table 4. Cross tabulation between Income and Payment Mode

\begin{tabular}{|c|c|c|c|c|c|c|c|}
\hline \multirow{2}{*}{\multicolumn{2}{|c|}{ Income }} & \multicolumn{5}{|c|}{ Payment Mode } & \multirow{3}{*}{$\begin{array}{l}\text { Total } \\
190\end{array}$} \\
\hline & & \multirow{2}{*}{$\begin{array}{l}\text { Cards } \\
20\end{array}$} & \multirow{2}{*}{$\begin{array}{l}\text { Internet Banking } \\
30\end{array}$} & \multirow{2}{*}{\begin{tabular}{|l|} 
UPI \\
45
\end{tabular}} & \multirow{2}{*}{$\begin{array}{l}\text { E-Wallet } \\
35\end{array}$} & \multirow{2}{*}{$\begin{array}{l}\text { Cash On Delivery } \\
60\end{array}$} & \\
\hline Below $50 \mathrm{~K}$ & count & & & & & & \\
\hline & Percentage & $3 \%$ & $5 \%$ & $7 \%$ & $6 \%$ & $10 \%$ & $31 \%$ \\
\hline \multirow[t]{2}{*}{$50 \mathrm{~K}-11 \mathrm{lakh}$} & count & 62 & 33 & 84 & 61 & 70 & 310 \\
\hline & Percentage & $10 \%$ & $6 \%$ & $13 \%$ & $10 \%$ & $11 \%$ & $50 \%$ \\
\hline \multirow[t]{2}{*}{ Above 1lakh } & count & 28 & 17 & 31 & 24 & 20 & 120 \\
\hline & Percentage & $5 \%$ & $2 \%$ & $5 \%$ & $4 \%$ & $3 \%$ & $19 \%$ \\
\hline \multirow[t]{2}{*}{ Total } & count & 110 & 80 & 160 & 120 & 150 & 620 \\
\hline & Percentage & $18 \%$ & $13 \%$ & $25 \%$ & $20 \%$ & $24 \%$ & $100 \%$ \\
\hline
\end{tabular}

Source: Primary data

From the table 4 , it is inferred that $13 \%$ of the total customers who earn between 50000 to 1 lakh INR prefer UPI; $11 \%$ of the customers in the same income category prefer cash on delivery option; each $10 \%$ of them prefer plastic cards (Credit/Debit cards) and E-Wallets (Electronic Wallets); and $10 \%$ of the customers who earn below 50000 prefer cash on delivery option. The summary of the findings states that majority of people with less income prefer cash on delivery option. The chi-square test value for the above table is 36.514 with degree of freedom is 8 . The probability value is 0.000 , which is below 0.05 . Hence the alternative hypothesis is accepted. Therefore the monthly income is related to the convenient payment mode.

\section{Conclusion}

The result from the data analysis indicates that both the education and the income of the customers are related to the customer's preference towards the convenient mode of payment during the online shopping. It is inferred that during COVID situation, the highly educated customers prefer the UPI and the E-Wallet mode of payment and the less educated prefer the cash on delivery (COD) option. It is suggested that the e-tailers may depict the Cash on delivery option in rural areas where the density of less educated people is high. Likewise, people with the less income prefer to the cash on delivery mode of payment, which indicate that still people with the lower income yet to adapt digitization while paying the bills to the e-tailers. From the above statements, it is concluded that still there is a large scope for penetration of digital payment technologies in India.

\section{References}

[1] Abu-Shamaa. R., Abu-Shamab.E. and Khasawneh.R., (2016), Payment Methods and Purchase Intention in Online Stores: An 
Empirical Study in Jordan, International Journal of E-Business Research,12(2), 31-44.

[2] Antinoja.R. and Scherling.D. (2019). The effect of e-payment methods on Online Purchasing Cancellation, Jonkoping University.

[3] Bandi.C., Moreno.A., Ngwe.D. and Xu.Z. (2019). The Effect of Payment Choice on Online Retail: Evidence from the 2016 Indian Demonetization, Harward Business School.

[4] Business Today(2021, July)., The e-tailing in India, Business today.

[5] Khan.S. and Jain.S. (2018). A study on Usage of e-Payments for sustainable growth of online business, IOSR Journal of Business and Management, 74-81.

[6] Mallesha.C. (2020). A Case study on Perception Towards Online Payment Systems Among Urban and Rural Customers, International Journal of Advanced Research in Commerce, Management and Social Science, 3(1), 196-204.

[7] Mchugh.M.L(2013)., The Chi-Squae Test of Independence, Biochemia Medica, 23(2),143-149.

[8] Siby.R.M. (2021). A study on consumer perception of digital Payment Methods in times of Covid Pandemic, Munich Personal Repec Archive. 